\title{
Late Bronze-Iron Age fortification complexes of the historical Javakheti region, Georgia
}

\author{
Dimitri Narimanishvili*
}

In 2017, archaeological survey recorded more than 160 Late Bronze-Iron Age cyclopean fortification complexes in the historical Javakheti region, Georgia. The author relates different types of cyclopean complexes mentioned in Urartian written sources to the sites found in Javakheti.

Keywords: Georgia, Bronze Age, Iron Age, Urartian, Cyclopean fortresses, fortification systems

Javakheti is an historical region located in the southern part of the country of Georgia. It is situated between the Mtkvari River to the west, the Javakheti and Trialeti mountain range to the east and north, and, in certain periods, it spread to the south, reaching the sources of the Mtkvari River. At present, Javakheti is part of the Samtskhe-Javakheti administrative unit (Akhalkalaki and Ninotsminda municipalities).

Based on Urartian written sources, some researchers identify Javakheti as the historical country of Zabahae, which was located at the sources of the Mtkvari River (Melikishvili 1960: 446). The Javakheti Plateau contains a series of prehistoric fortresses known as cyclopean complexes - structures built with dry-masonry (Figure 1) — which are generally dated to between the Late Bronze Age and the end of the Iron Age (G. Narimanishvili 2012: 139). These form part of a wider phenomenon of cyclopean complexes spread throughout the territories of modern Georgia, Turkey, Armenia, Azerbaijan and Iran. This article discusses the results of an archaeological survey conducted in the historical Javakheti region in 2017. The aim of the project was to record the Late Bronze-Iron Age fortress complexes.

Scientific research on megalithic sites in Georgia has been ongoing for more than 130 years. The importance of these sites was discussed at the fifth Archaeological Meeting, held in Tbilisi in 1881. Cyclopean fortresses have long been at the centre of the study of Late Bronze-Early Iron Age history, architecture and constructive art in the South Caucasus. Recent research has begun to link South Caucasian cyclopean complexes to early state formations (Daiaeni/Diaukhi) including those (Zabahae, Tariuni and the like) mentioned in Assyrian and Urartian written sources (G. Narimanishvili 2012: 141; D. Narimanishvili 2016: 213; Narimanishvili et al. 2017: 129-30). Written sources from the neighbouring empire of Urartu specifically mention fortified complexes, as well as providing information about the social structure and economy of the small states in the region.

\footnotetext{
Georgian National Museum, 3/10 Shota Rustaveli Avenue, T'bilisi 0105, Georgia

* Author for correspondence (Email: d.narimanishvili@yahoo.com)
} 


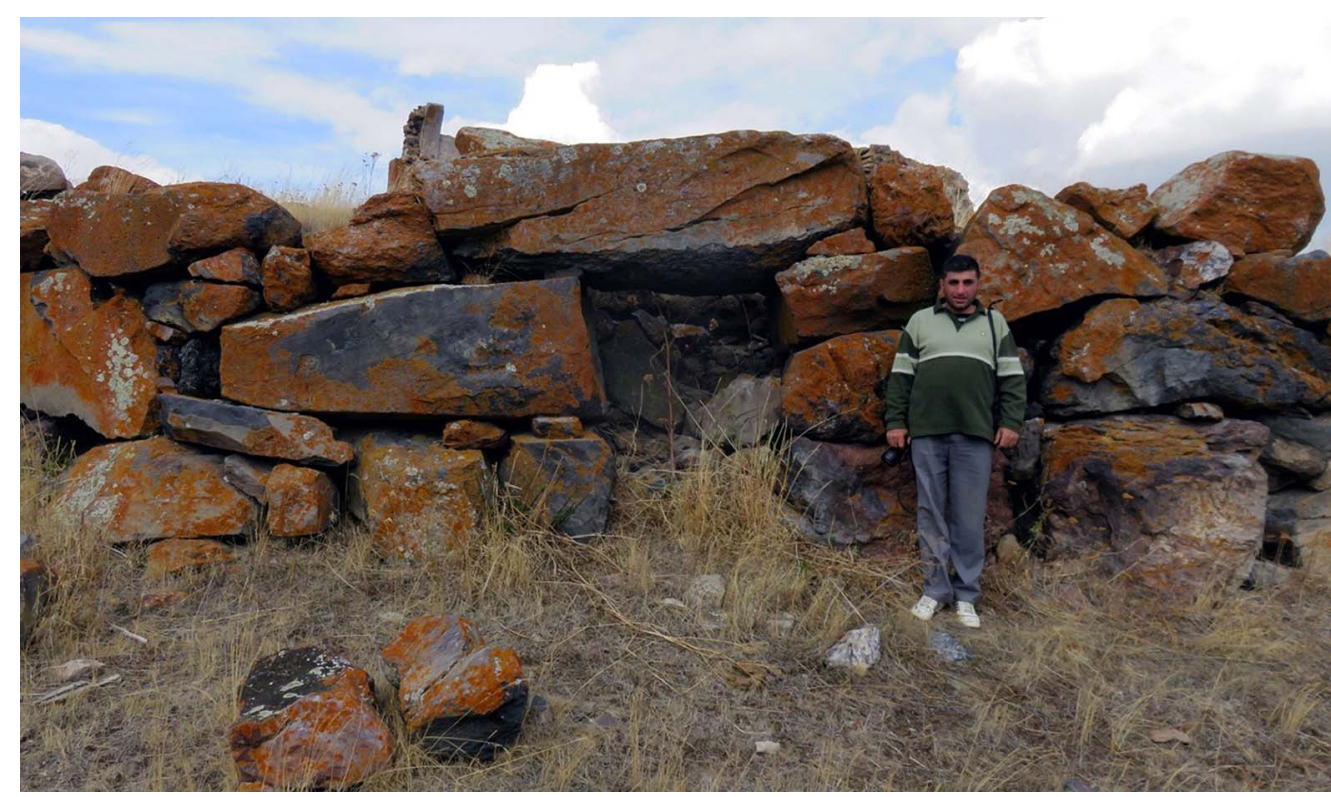

Figure 1. Cyclopean structure in the village of Aspara (photograph by D. Narimanishvili).

The project aims included producing a complete list of all known fortresses and recording each one in the field. Before fieldwork, I undertook a thorough literature review, as well as using Soviet-era and more recent (Google Earth, Zoom Earth and Bing Aerial) aerial photographs as a form of desk-based assessment. All possible sites were visited, described and photographed, and their coordinates were recorded; this enabled the creation of a database. This research shows that the greatest concentration of cyclopean complexes in southern Georgia is found on the Javakheti Plateau, where 162 complexes were documented, of which 84 were previously unknown (Figure 2).

Urartian and Assyrian written sources give information about the structure of the cyclopean complexes in the South Caucasus. Sources suggest that three kinds of fortified complexes coexisted within the territory of Diaukhi and its surrounding polities: 'Royal cities', 'towns' and 'fortresses' (e.g. Melikishvili 1954: 215). 'Royal cities' were apparently administrative centres, which were well protected, evidenced by the fact that the well-furnished Urartian army struggled to conquer them. It seems from Urartian written sources that the small settlements surrounding the royal cities were referred to as towns.

As part of the project, I attempted to fit the cyclopean fortresses into the categories described in the Urartian written sources. Large settlements (0.8-10ha in size) in the region with complicated fortification systems, including complexes of large walls and dry moats, often constructed on prominent, difficult-to-reach mountaintops (Figures 3-4), were identified as 'royal cities'. The settlements around these cities are located in less prominent positions (Figure 5) and are protected by a wall and a dry moat, and are referred to as 'towns'. A 'fortress' can be identified as a complex that is established in a strategic place, often at points of control in the landscape where routes may have met. In some cases, all three types of (C) Antiquity Publications Ltd, 2019 


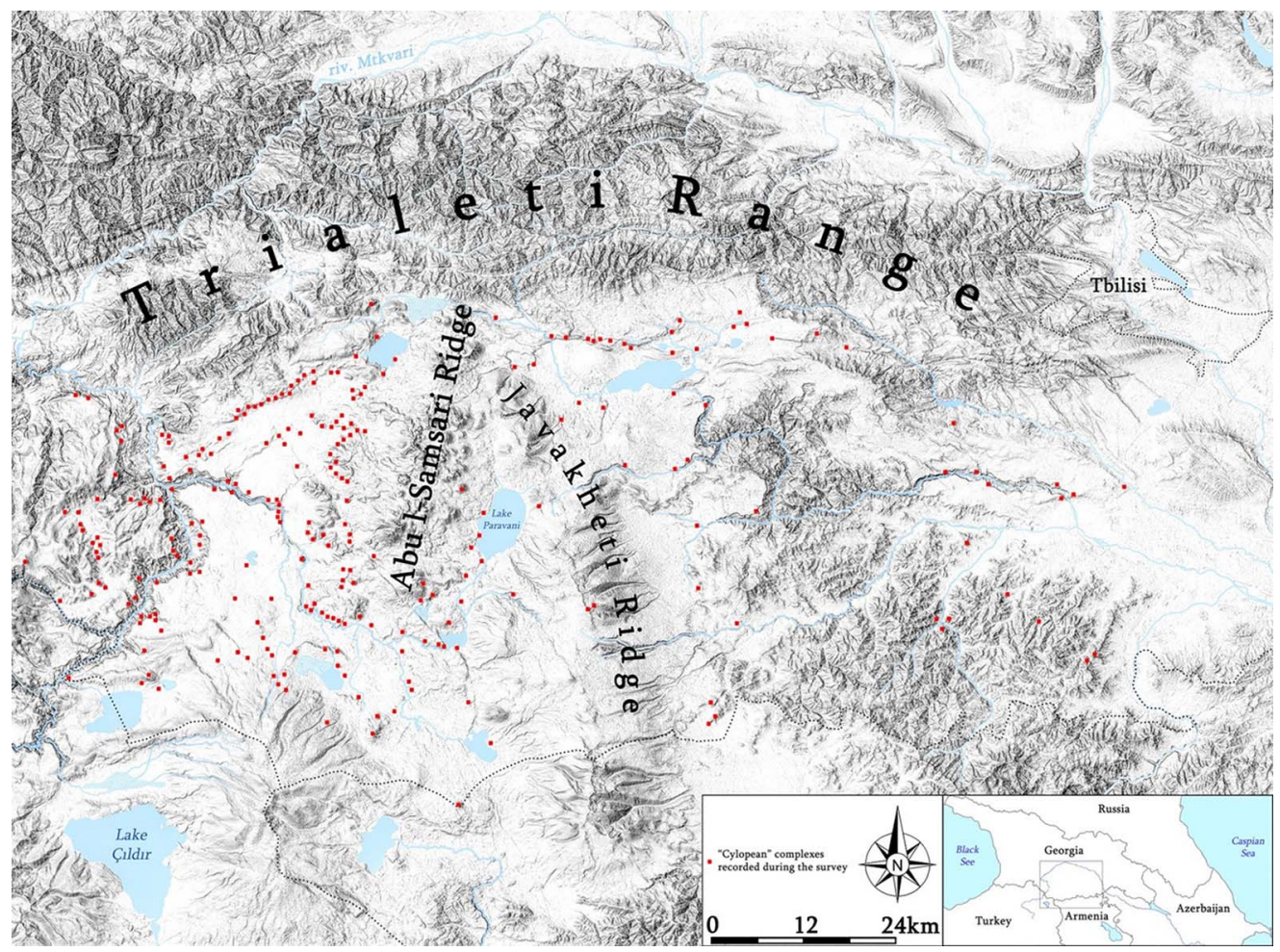

Figure 2. Spread of cyclopean complexes in southern Georgia (map by D. Narimanishvili).

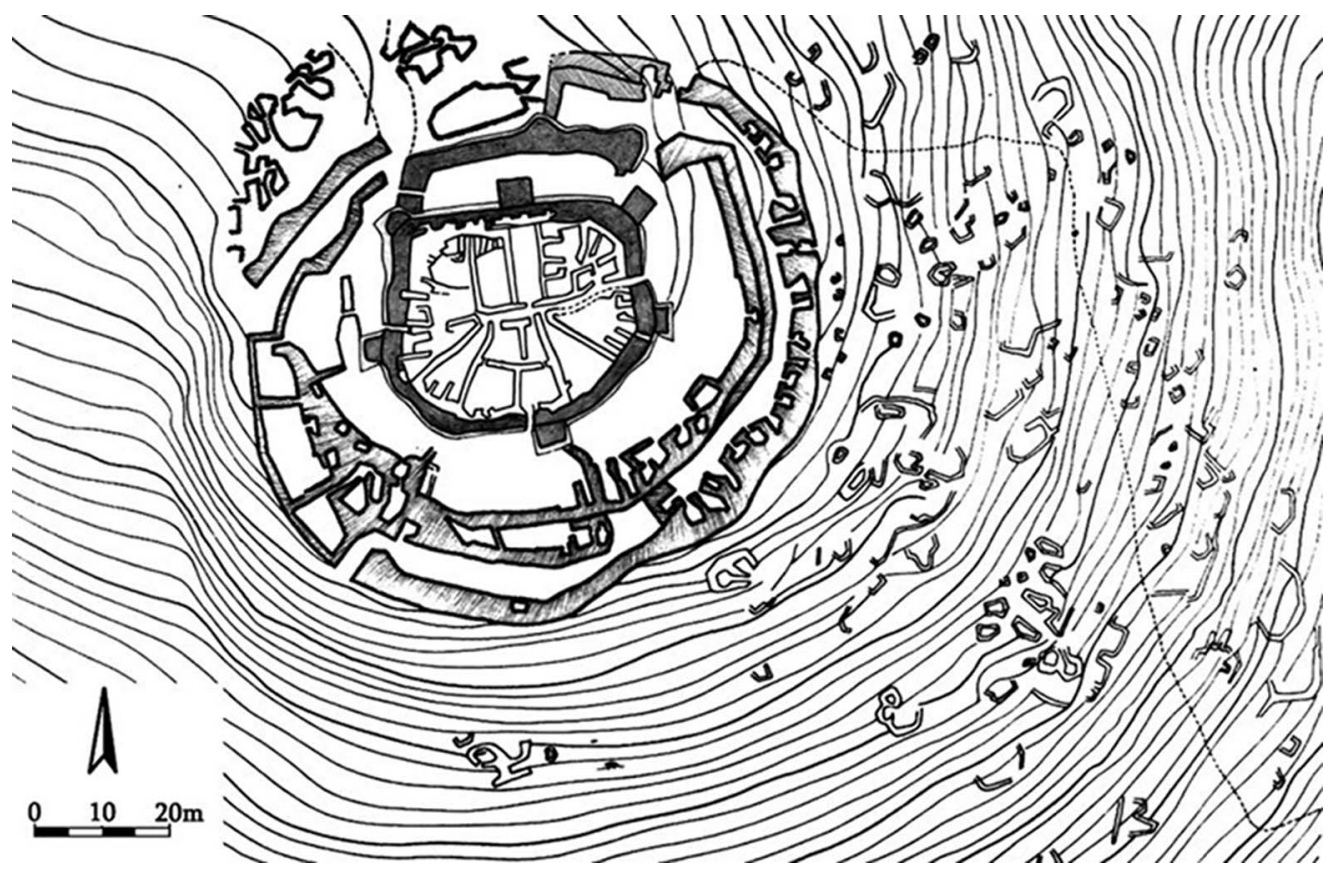

Figure 3. Plan of the cyclopean complex of Abuli (G. Narimanishvili 2012: 188).

(C) Antiquity Publications Ltd, 2019 


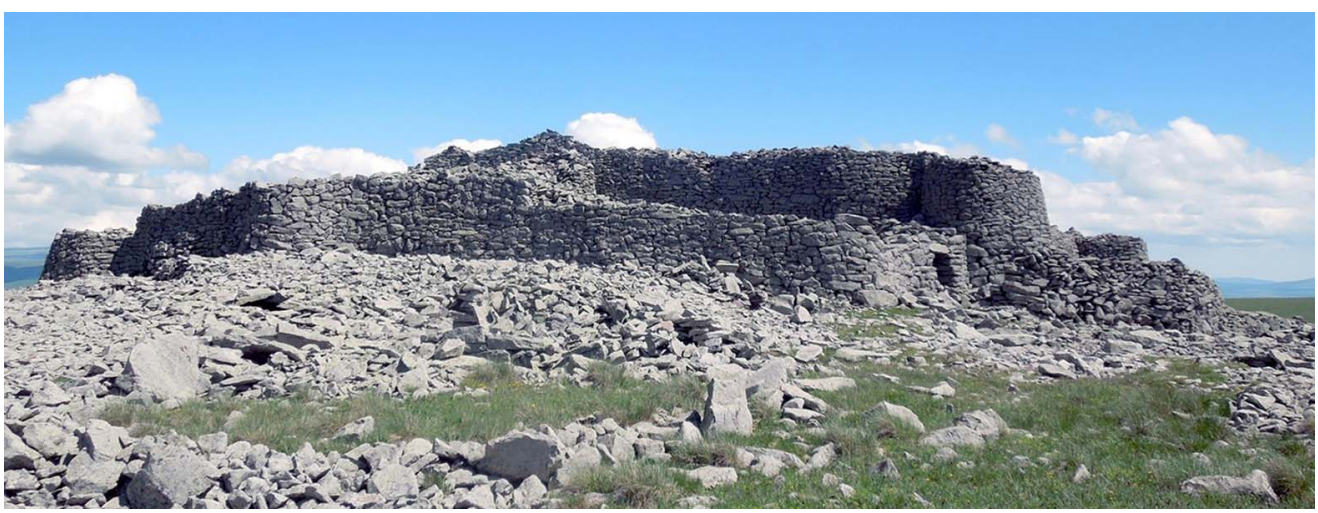

Figure 4. Citadel of the cyclopean complex of Abuli (photograph by D. Narimanishvili).

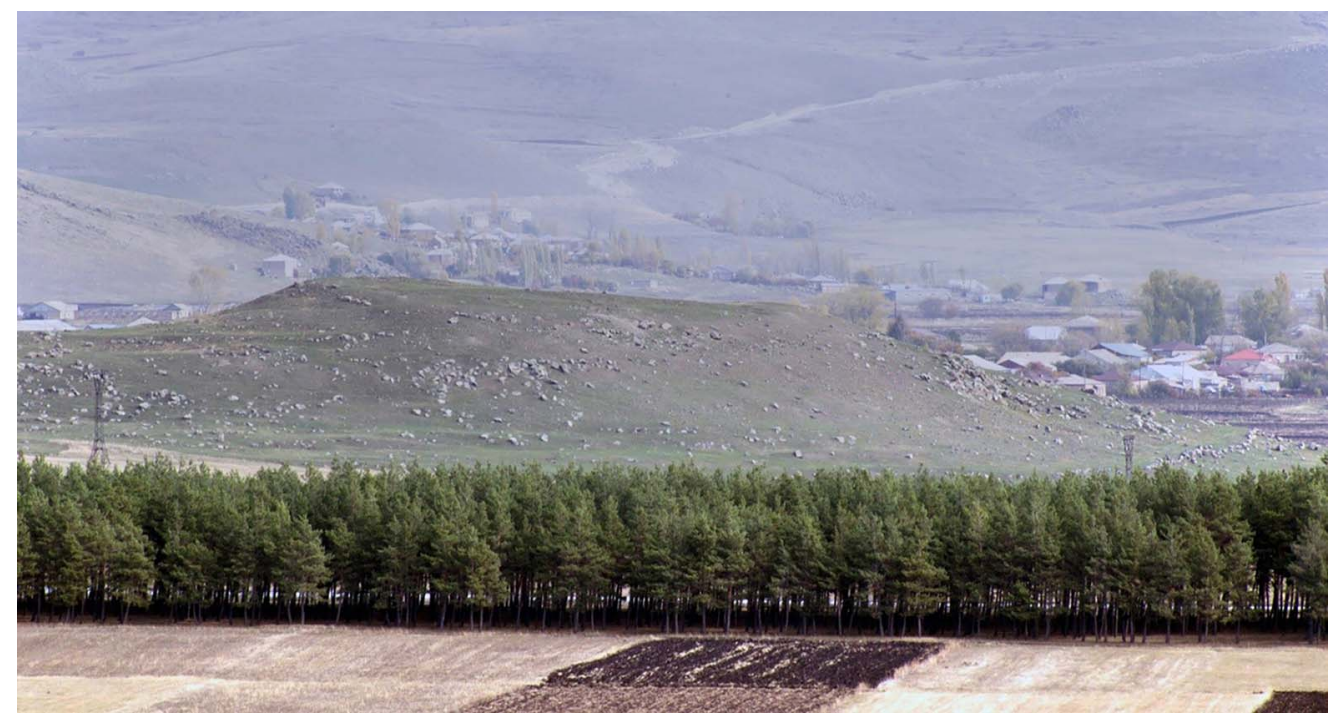

Figure 5. Fortified settlement near Baraleti Village (photograph by D. Narimanishvili).

complexes are located in close proximity to each other, sometimes making use of the natural landscape to create a single fortification system-a 'local region' (Figure 6).

At the end of the fourteenth century BC, the political and economic situation in the South Caucasus and Anatolia changed radically, due in part to the fall of the Mitanni Empire. The trade network, which supplied north Mesopotamia and the Levant with different raw materials, collapsed and the Assyrian and later Urartian empires expanded (Shanshashvili \& Narimanishvili 2012: 178-79). To the north, Assyria and Urartu were bordered by more fluid political configurations in the highlands of Eastern Anatolia and the South Caucasusareas rich in metal. A list of tributes charged to the South Caucasian 'countries' by the Assyrian and Urartian kings shows that metals were supplied, along with other resources.

(C) Antiquity Publications Ltd, 2019 

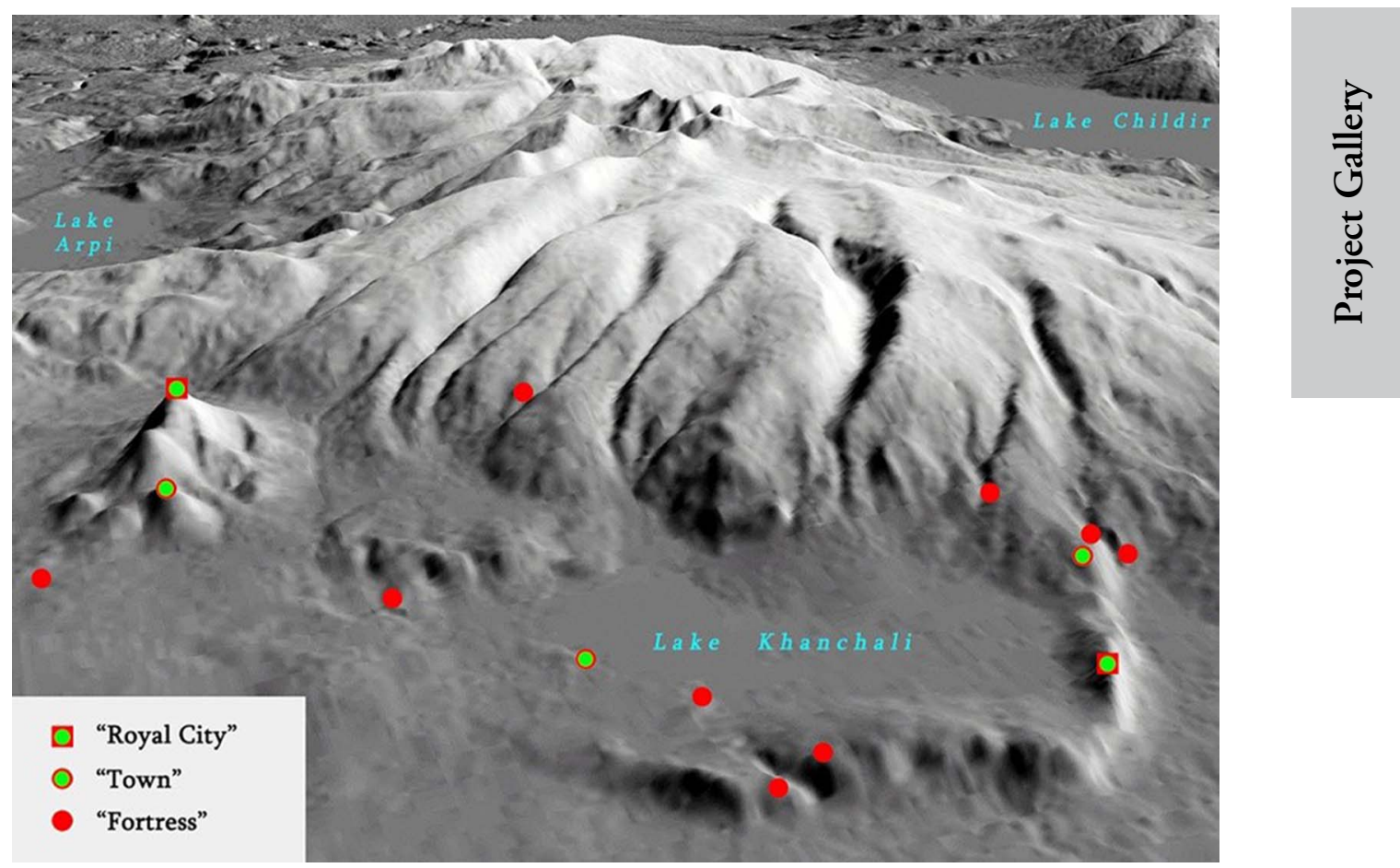

Figure 6. Concentration of cyclopean structures around Lake Khanchali (image by D. Narimanishvili).

The expansionist tendencies of both the Assyrian and Urartian empires brought them into conflict with the groups occupying the South Caucasus. The aims of the imperial powers were to control the metallurgical centres and trade routes, as well as to extract tribute (Bongard-Levin 1988: 103 \& 108). This was probably the impetus for local tribes to unite in the struggle against these enemies (Melikishvili 1954: 251-55). The resistance of the population of the South Caucasus to empirical expansion from the south is reflected in the intense construction of protective fortification systems.

\section{Acknowledgements}

This work was supported by the Shota Rustaveli National Science Foundation (\#YS-2016-67, Megalithic Fortification Systems in Georgia).

\section{References}

Bongard-Levin, G.M. (ed.). 1988. History of the ancient east. Moscow: Publishing House of the Main Editorial Office of Eastern Literature - 'Nauka' (in Russian).

Melikishvili, G. 1954. Nairi-Urartu. Tbilisi: Publishing House of the Academy of Sciences of the Georgian SSR (in Russian).
- 1960. Urartskie klinoobraznie nadpisi. Moscow: Publishing House of the Academy of Sciences of the USSR (in Russian).

Narimanishvili, D. 2016. The cyclopean settlements of South Georgia and the prospects for its study, in N. Shanshashvili (ed.) Aegean world and South Caucasus: cultural relations in the Bronze Age: 210-15. Tbilisi: Printing house 'Mtsignobari'. 
NarimanishVili, D., R. VAdachKoria, K. Tamazashvili, K. Juszczyk \& W. Tomczyк. 2017. Archaeological excavations at Beshtasheni Late Bronze Age-Early Iron Age cemetery, in ARAMAZD: Armenian Journal of Near Eastern Studies XI: 120-44: Oxford: Archaeopress.

Narimanishvili, G. 2012. Trialeti settlements of Bronze Age synopsis, in G. Kipiani (ed.) Issues of the history and archaeology of Georgia and
Caucasus: 128-93. Tbilisi: Ilia State University Press.

Shanshashvili, N. \& G. Narimanishvili. 2012. Late Bronze/Early Iron Age sites in Trialetiexternal relations and cultural contacts, in A. Menhert, G. Menhert \& S. Reinhold (ed.) Austausch und Kulturkontaktim Südkaukasus und seinenangrenzenden Regionen in der Spätbronze-Früheisenzeit: 175-94. Langenweißbach: Beier \& Beran.

(C) Antiquity Publications Ltd, 2019 